\title{
Comparison of body temperature and heart rate in sea turtles from Baja California Sur, Mexico
}

\section{Comparación de temperatura corporal y frecuencia cardíaca en tortugas marinas de Baja California Sur, México}

\author{
Helena Fernández-Sanz ${ }^{1,2 *}$, Eduardo Reséndiz ${ }^{1,2}$ \\ ${ }^{1}$ Departamento Académico de Ciencias Marinas y Costeras, Universidad Autónoma de Baja California Sur, \\ Carretera al Sur, km 5.5, El Mezquitito 19-B, 23080, La Paz, Baja California Sur, Mexico. \\ ${ }^{2}$ Health assessments in sea turtles from Baja California Sur, Villa Ballena 330, Villas del Encanto, 23085, La \\ Paz, Baja California Sur, Mexico. \\ * Corresponding author. E-mail: helena.fdezsanz@gmail.com
}

\begin{abstract}
Sea turtles depend on ambient temperature to carry out their main activities, so changes in water temperature can affect the function of their immune system and represent different threats. To assess vital signs in black sea turtles (Chelonia mydas) in the Ojo de Liebre lagoon complex, Mexico, 600 turtles were examined. Carapace, plastron, and left inguinal area temperatures were measured with a digital infrared thermometer gun. Cloacal temperature was measured with an electronic thermometer. Heart rate was recorded using a stethoscope. Statistical analyses found no significant variation between inguinal area and cloacal temperatures. Vital sign measurements were compared with previous reports in the region, and there were differences in body temperatures, which were attributed to the characteristics of the water masses inhabited by the turtles. There was no significant difference between heart rate data for black sea turtles in this study and previously reported data for healthy sea turtles in the region, indicating that these data are likely an accurate representation for the species. All values fell within the reference intervals for healthy sea turtles. This minimally invasive diagnostic approach using vital signs allowed us to evaluate and infer core organ functions and to rule out health threats such as cold-stunning, resulting in a useful preliminary systemic assessment of freeranging sea turtles.
\end{abstract}

Key words: vital signs, black turtles, loggerhead turtles, health assessment, conservation.

RESUMEN. Las tortugas marinas dependen de la temperatura ambiental para llevar a cabo sus actividades principales, por lo que los cambios en la temperatura del agua pueden afectar la función de su sistema inmunológico y representar diferentes amenazas. Para evaluar los signos vitales de las tortugas negras (Chelonia mydas) del complejo lagunar Ojo de Liebre, México, se examinaron 600 tortugas. Las temperaturas de caparazón, plastrón y área inguinal izquierda se midieron con un termómetro digital infrarrojo. La temperatura cloacal se midió con un termómetro electrónico. La frecuencia cardíaca se registró con un estetoscopio. No se encontraron diferencias significativas entre las temperaturas del área inguinal izquierda y cloacales. Los valores de los signos vitales se compararon con reportes previos en la región, y hubo diferencias en las temperaturas corporales, las cuales fueron atribuidas a las características de las masas de agua en las que habitan las tortugas. No hubo diferencias significativas entre datos de frecuencia cardíaca de las tortugas negras de este estudio y los datos reportados previamente para tortugas marinas sanas en la región, lo cual sugiere que estos datos son una representación precisa de las especies. Todos los valores estuvieron dentro de los intervalos de referencia para tortugas marinas sanas. Este enfoque diagnóstico mínimamente invasivo por medio de signos vitales nos permitió evaluar e inferir funciones fisiológicas centrales básicas y descartar amenazas como frío paralizante, lo cual resulta útil como evaluación sistémica inicial de tortugas marinas en vida libre.

Palabras clave: signos vitales, tortugas negras, tortugas amarillas, evaluación de salud, conservación.

\section{INTRODUCTION}

Sea turtles are exposed to a wide range of environmental changes in each of their life stages, so assessing their health is of paramount importance (Aguirre and Lutz 2004). These ectothermic organisms depend on ambient temperature to carry out their main activities, so changes in water temperature can affect the function of their immune system and represent different threats (Foley et al. 2007, Hunt et al. 2019). Although sea turtles have thermoregulatory adaptations that allow them to save energy and maintain

\section{INTRODUCCIÓN}

Las tortugas marinas están expuestas a una amplia gama de cambios ambientales en cada una de sus etapas de vida $y$, por lo tanto, evaluar su salud es de suma importancia (Aguirre y Lutz 2004). Estos organismos ectotérmicos dependen de la temperatura ambiental para realizar sus principales actividades, por lo que los cambios en la temperatura del agua pueden afectar el funcionamiento de su sistema inmunológico y representar diferentes amenazas (Foley et al. 2007, Hunt et al. 2019). A pesar de que las tortugas marinas tienen 
stable body temperatures, such as torpor (Southwood et al. 2003), when temperatures drop below $10{ }^{\circ} \mathrm{C}$, they become lethargic and are unable to swim or dive, entering a status of hypothermia (Schwartz 1978, Innis et al. 2007) that disrupts metabolic pathways leading to imbalances in their different systems (Innis et al. 2007). Changes in temperature may also increase the risk of infectious diseases such as fibropapillomatosis (Arthur et al. 2008, Van Houtan et al. 2014). Monitoring vital signs is therefore important for physiological and medical assessments and it becomes a basic tool for the conservation of these species. In laboratory studies with captive turtles, physical factors such as temperature can be controlled and metabolic and physiological responses can be closely monitored (Southwood et al. 2003); however, in free-ranging populations handling sea turtles is often more complicated, so improving some methods and techniques used in their health assessment can facilitate vital-sign monitoring and even sample collection (Reséndiz et al. 2019). The aims of this study were to (1) assess body temperature and heart rate in black turtles (Chelonia mydas) in the Ojo de Liebre lagoon complex, Baja California Sur, Mexico; (2) validate a novel, non-invasive temperature measurement technique; and (3) compare the body temperature and heart rate data obtained in this study with previous reports.

\section{MATERIALS AND METHODS}

Ojo de Liebre Lagoon (OLL) and Guerrero Negro Lagoon (GNL) in the Ojo de Liebre lagoon complex are part of El Vizcaíno Biosphere Reserve, on the northern Pacific coast of Baja California Sur (Mexico). These coastal lagoons are located between latitude 27.5833 and $28.25^{\circ} \mathrm{N}$ and longitude 113.8333 and $114.3333^{\circ} \mathrm{W}$, and they are characterized by having extensive shallow, hypersaline areas, no contributions of fresh water, high evaporation, and mean sea surface temperatures of $21.29^{\circ} \mathrm{C}(\mathrm{OLL})$ and $20.53^{\circ} \mathrm{C}(\mathrm{GNL})$ (ESSA 2018). Both lagoons are inhabited by black turtles (Reséndiz et al. 2018), which were considered a single group of organisms because of the geographical proximity of both lagoons and the similarity in habitat characteristics.

A total of 20 field trips were carried out from May 2017 to December 2019 to capture black turtles in OLL and GNL. All captures were made using monofilament nets ( $100 \mathrm{~m}$ long by $5 \mathrm{~m}$ deep, $60-\mathrm{cm}$ mesh width) during daylight hours. Nets were periodically checked every hour to avoid excess stress on the turtles and to minimize lesion risk.

To assess vital signs, the turtles were systematically examined in detail in prone and supine positions on the boat (Reséndiz et al. 2018). The carapace, plastron, and left inguinal area skin temperatures were taken with a digital infrared thermometer gun (Steren HER-425); the gun was held at a distance of $10 \mathrm{~cm}$ from the surface of each area, and temperatures were taken immediately (1-30 seconds) after the turtles were captured. For each anatomical region, adaptaciones termorreguladoras que les permiten ahorrar energía y mantener estable su temperatura corporal, como el estado de sopor (Southwood et al. 2003), cuando las temperaturas descienden por debajo de los $10^{\circ} \mathrm{C}$, se vuelven letárgicas y no pueden nadar o bucear, lo que las hace entrar en un proceso de hipotermia (Schwartz 1978, Innis et al. 2007) que interrumpe las vías metabólicas y puede conducir a desequilibrios en sus diferentes sistemas (Innis et al. 2007). Los cambios de temperatura también pueden aumentar el riesgo de enfermedades infecciosas como la fibropapilomatosis (Arthur et al. 2008, Van Houtan et al. 2014). Por lo tanto, el monitoreo de los signos vitales es importante para la evaluación fisiológica y médica, y se convierte en una herramienta básica para la conservación de estas especies. En estudios de laboratorio con tortugas en cautiverio es posible controlar factores físicos como la temperatura y se pueden monitorear de cerca las respuestas metabólicas y fisiológicas (Southwood et al. 2003); sin embargo, en poblaciones en libertad, el manejo de las tortugas marinas suele ser más complejo. Es por ello que mejorar algunos métodos y técnicas utilizadas en su evaluación de salud puede facilitar el monitoreo de los signos vitales e incluso la recolección de muestras (Reséndiz et al. 2019). Los objetivos de este estudio fueron: (1) evaluar la temperatura corporal y la frecuencia cardíaca de las tortugas negras (Chelonia mydas) en el complejo lagunar Ojo de Liebre, Baja California Sur, México; (2) validar una nueva técnica no invasiva para el registro de la temperatura corporal; y (3) comparar los datos de temperatura corporal y frecuencia cardíaca obtenidos en este estudio con reportes anteriores.

\section{MATERIALES Y MÉTODOS}

La laguna Ojo de Liebre (LOL) y la laguna Guerrero Negro (LGN) del complejo lagunar Ojo de Liebre forman parte de la Reserva de la Biosfera El Vizcaíno, ubicada en la costa del Pacífico del norte de Baja California Sur (México). Estas lagunas costeras se ubican entre la latitud 27.5833 y $28.25^{\circ} \mathrm{N}$ y la longitud 113.8333 y $114.3333^{\circ} \mathrm{W}$, y se caracterizan por sus aguas someras hipersalinas, aportes nulos de agua dulce, alta evaporación y temperaturas superficiales del mar medias de $21.29{ }^{\circ} \mathrm{C}$ (LOL) y $20.53{ }^{\circ} \mathrm{C}$ (LGN) (ESSA 2018). Ambas lagunas están habitadas por tortugas negras (Reséndiz et al. 2018), las cuales fueron consideradas un solo grupo de organismos por la proximidad geográfica entre LOL y LGN, y la similitud en las características de sus hábitats.

Se realizaron un total de 20 salidas de campo desde mayo de 2017 hasta diciembre de 2019 para capturar tortugas negras en LOL y LGN. Todas las capturas se realizaron con redes de monofilamento ( $100 \mathrm{~m}$ de largo por $5 \mathrm{~m}$ de profundidad, luz de malla de $60 \mathrm{~cm}$ ) durante periodos diurnos. Las redes fueron revisadas cada hora para evitar el estrés excesivo de las tortugas y minimizar el riesgo de lesiones.

Para evaluar los signos vitales, las tortugas fueron examinadas en decúbito prono y supino con una inspección 
Fernández-Sanz and Reséndiz: Comparison of vital signs in sea turtles from Baja California Sur

temperature was measured 3 times and the mean was calculated (Reséndiz et al. 2018). Cloacal temperature was measured with an electronic thermometer (Suretemp Plus 690, Welch Allyn). During the physical examination and after resting for $10 \mathrm{~min}$ alone in a free space, the turtles were auscultated with a stethoscope (IUMED model 400), which was placed on the skin between the neck and the proximal front flipper. The curved carapace length (CCL, centimeters) and turtle weight (kilograms) were then recorded (Bolten 1999); immediately after, the turtles were aseptically tagged with metallic Inconel 681 tags (National Band \& Tag) in the skin of the distal hind limbs (Balazs 1999) and released. Black turtles under $77.5 \mathrm{~cm}$ CCL were considered juveniles and those $77.5 \mathrm{~cm}$ CCL or over were classified as adults according to Márquez (1990).

For this study, juvenile and adult turtles were considered a single group of organisms since there were no significant differences in temperature and heart rate between age classes $(P<0.05)$. The Kolmogorov-Smirnov statistic, skewness, and kurtosis were used to test data for normality. The mean and standard deviation were determined for each variable. Student's $t$-tests between cloacal (control) temperature and carapace, plastron, and inguinal area temperatures were performed to assess the effectiveness of the temperature measurements. A linear regression between cloacal and inguinal area temperatures was made for black turtles examined in the present study. Comparisons of cloacal temperature and heart rate between black turtles examined in the present study, black turtles in OLL and San Ignacio Lagoon (SIL) (Reséndiz et al. 2018), and loggerhead turtles (Caretta caretta) in the Gulf of Ulloa (GU, Reséndiz et al. 2019) were made using a one-way analysis of variance, and specific between-group differences were evaluated using a Tukey's test. Values of $P<0.05$ were considered statistically significant. Statistical analyses were performed using R v.3.6.2 (Integrated Development for R. RStudio; Boston, MA).

\section{ReSULTS}

A total of 600 black turtles measuring $72.38 \pm 7.54 \mathrm{~cm}$ CCL and weighing $42.24 \pm 20.80 \mathrm{~kg}$ were captured. OLL and GNL turtles were classified as juveniles and adults and determined clinically healthy according to physical examination. Data on morphometrics and vital signs (body temperatures and heart rate) are shown in Table 1. There was no significant difference between cloacal temperature and inguinal area temperature for black turtles from the present study $(P=0.13)$, and both variables showed a positive linear relationship $\left(R^{2}=0.44\right.$, Fig. 1$)$. There was significant variation in cloacal temperatures between the 4 groups of marine turtles $(F=4.33$, d.f. $=3, P<0.05)$ (Fig. 2a). A Tukey's post hoc test indicated that cloacal temperatures for black turtles in the present study $\left(20.74 \pm 2.82^{\circ} \mathrm{C}\right)$ and those for black turtles in OLL $\left(19.85 \pm 2.25^{\circ} \mathrm{C}\right)$ (Reséndiz et al. 2018) detallada y sistemática en la embarcación (Reséndiz et al. 2018). Las temperaturas del caparazón, del plastrón y del área inguinal izquierda se registraron con un termómetro infrarrojo digital tipo pistola (Steren HER-425), el cual se colocó a una distancia de $10 \mathrm{~cm}$ de la superficie de cada área. Las temperaturas se registraron inmediatamente (1-30 segundos) después de la captura de las tortugas. Para cada región anatómica, la temperatura se registró 3 veces y se calculó la media (Reséndiz et al. 2018). La temperatura cloacal se midió con un termómetro electrónico (Suretemp Plus 690, Welch Allyn). Durante el examen físico y después de $10 \mathrm{~min}$ solas en un espacio libre, las tortugas fueron auscultadas con un estetoscopio (IUMED modelo 400), el cual se colocó sobre la piel entre el cuello y la aleta anterior izquierda. A continuación, se registró el largo curvo del caparazón (LCC, centímetros) y el peso de la tortuga (kilogramos) (Bolten 1999); inmediatamente después, las tortugas fueron marcadas asépticamente con placas metálicas Inconel 681 (National Band \& Tag) en las aletas traseras (Balazs 1999) y liberadas ilesas. Las tortugas negras menores que $77.5 \mathrm{~cm}$ de LCC fueron consideradas juveniles, y aquellas con $77.5 \mathrm{~cm}$ de LCC o más fueron clasificadas como adultas de acuerdo con Márquez (1990).

Estadísticamente, las tortugas juveniles y adultas se consideraron un solo grupo de organismos, ya que no hubo diferencias significativas en la temperatura y la frecuencia cardíaca entre las clases de edad $(P<0.05)$. Para evaluar la normalidad de los datos se utilizó la prueba de Kolmogorov-Smirnov, la asimetría y la curtosis. Se determinaron la media y la desviación estándar de cada variable. Para evaluar la efectividad de las mediciones de temperatura, se realizaron pruebas $t$ de Student entre la temperatura cloacal (control) y la temperatura del caparazón, la temperatura del plastrón y la temperatura del área inguinal izquierda. Adicionalmente, se realizó una regresión lineal entre las temperaturas cloacales e inguinales de las tortugas negras del presente estudio. Mediante un análisis de varianza de una vía se comparó la temperatura cloacal y la frecuencia cardíaca entre las tortugas negras del presente estudio, las tortugas negras de LOL y laguna San Ignacio (LSI) (Reséndiz et al. 2018) y las tortugas amarillas (Caretta caretta) del golfo de Ulloa (GU) (Reséndiz et al. 2019). Las diferencias específicas entre grupos se evaluaron mediante una prueba de Tukey. Los valores de $P<0.05$ se consideraron estadísticamente significativos. Todos los análisis se realizaron utilizando el software R v.3.6.2 (Integrated Development for R. RStudio; Boston, MA).

\section{Resultados}

Se capturaron un total de 600 tortugas negras con LCC de $72.38 \pm 7.54 \mathrm{~cm}$ y peso de $42.24 \pm 20.80 \mathrm{~kg}$. Las tortugas de LOL y LGN se clasificaron como juveniles y adultas, y se consideraron clínicamente sanas con base en el examen físico. Los datos morfométricos y de signos vitales (temperatura corporal y frecuencia cardíaca) se muestran en la Tabla 1. 
Table 1. Morphometrics, body temperature, and heart rate of sea turtles from Baja California Sur (Mexico). OLL: Ojo de Liebre Lagoon; GNL: Guerrero Negro Lagoon; SIL: San Ignacio Lagoon; GU: Gulf of Ulloa; SD: standard deviation; CCL: curved carapace length; T: temperature. Values are given as the mean \pm standard deviation.

Tabla 1. Morfometría, temperatura corporal y frecuencia cardíaca de tortugas marinas de Baja California Sur (México). OLL: laguna Ojo de Liebre; GNL: laguna Guerrero Negro; SIL: laguna San Ignacio; GU: golfo de Ulloa; SD: desviación estándar; CCL: largo curvo de caparazón; T: temperatura. Los valores se expresan como la media \pm desviación estándar.

\begin{tabular}{|c|c|c|c|c|}
\hline & Black turtles & Black turtles (OLL) & Black turtles (SIL) & Loggerheads (GU) \\
\hline & $\begin{array}{l}\text { Present research } \\
\qquad(n=600)\end{array}$ & $\begin{array}{l}\text { Reséndiz et al. (2018) } \\
\qquad(n=59)\end{array}$ & $\begin{array}{l}\text { Reséndiz et al. (2018) } \\
\qquad(n=20)\end{array}$ & $\begin{array}{l}\text { Reséndiz et al. (2019) } \\
\qquad(n=56)\end{array}$ \\
\hline $\operatorname{CCL}(\mathrm{cm})$ & $72.38 \pm 7.54$ & $75.61 \pm 4.48$ & $51.37 \pm 3.71$ & $63.49 \pm 8.06$ \\
\hline Weight $(\mathrm{kg})$ & $42.24 \pm 20.80$ & $40.94 \pm 18.92$ & $18.39 \pm 1.50$ & $36.14 \pm 22.51$ \\
\hline Carapace $\mathrm{T}\left({ }^{\circ} \mathrm{C}\right)$ & $22.34 \pm 4.28$ & $23.33 \pm 3.97$ & $22.76 \pm 3.91$ & $27.27 \pm 3.01$ \\
\hline Plastron $\mathrm{T}\left({ }^{\circ} \mathrm{C}\right)$ & $21.84 \pm 4.61$ & $22.61 \pm 3.40$ & $23.27 \pm 4.10$ & $24.50 \pm 2.70$ \\
\hline Inguinal area $\mathrm{T}\left({ }^{\circ} \mathrm{C}\right)$ & $21.07 \pm 3.11$ & $21.22 \pm 3.43$ & $22.20 \pm 2.95$ & $21.01 \pm 3.20$ \\
\hline Cloacal T $\left({ }^{\circ} \mathrm{C}\right)$ & $20.74 \pm 2.82$ & $19.85 \pm 2.25$ & $22.42 \pm 3.13$ & $20.97 \pm 3.60$ \\
\hline Heart rate (beats/min) & $37.43 \pm 3.47$ & $37.41 \pm 2.95$ & $38.27 \pm 4.09$ & $41.38 \pm 6.04$ \\
\hline
\end{tabular}

were significantly lower than cloacal temperatures for black turtles in SIL $\left(22.42 \pm 3.13^{\circ} \mathrm{C}\right)$ (Reséndiz et al. 2018). There was no significant variation in mean heart rates between the 4 groups $(F=0.53$, d.f. $=3, P=0.66)$ (Fig. 2b).

\section{DiscuSSION}

In sea turtles cloacal temperature can be representative of ambient temperature (Southwood et al. 2003, Foley et al. 2007). By using data from healthy organisms as reference intervals, wildlife rehabilitators can more rapidly respond to events of cold-stunned turtles, increasing their chances of recovery (Wyneken et al. 2006). However, the technique for taking cloacal temperature is moderately invasive and may be painful for organisms (Manire et al. 2017). The left inguinal area temperature values reported in the present study coincided with the body temperature value previously reported for healthy turtles (Southwood et al. 2003, Hunt et al. 2019), and the present study confirmed that the use of the digital infrared thermometer in the left inguinal area is an easier, effective, and less invasive measurement technique. Although both areas showed a positive statistical relationship, the value of $R^{2}$ is medium-low and must be interpreted carefully. We recommend using this type of thermometer (properly calibrated) and recording body temperature when the turtle has just been captured in order to obtain the most representative values and avoid bias due to stress or external factors such as ambient temperature. The comparison of temperature between groups showed that cloacal temperatures were significantly higher in SIL turtles than in OLL and GNL turtles, which can be attributed to the conditions of the water masses they inhabit. OLL and GNL are interconnected and together occupy an area of $381 \mathrm{~km}^{2}$ (Contreras
No hubo diferencia significativa entre la temperatura cloacal y la temperatura del área inguinal izquierda de las tortugas de este estudio $(P=0.13)$, y ambas variables mostraron una relación lineal positiva $\left(R^{2}=0.44\right.$, Fig. 1$)$. Por otro lado, las temperaturas cloacales presentaron diferencias significativas entre los 4 grupos de tortugas marinas $(F=4.33$, g.l. $=3$, $P<0.05$ ) (Fig. 2a). Mediante la prueba post hoc de Tukey, se identificó que las temperaturas cloacales de las tortugas negras del presente estudio $\left(20.74 \pm 2.82^{\circ} \mathrm{C}\right)$ y las de las tortugas negras de LOL $\left(19.85 \pm 2.25^{\circ} \mathrm{C}\right.$ ) (Reséndiz et al. 2018) fueron significativamente más bajas que las temperaturas cloacales de las tortugas negras de LSI (22.42 \pm $3.13{ }^{\circ} \mathrm{C}$ ) (Reséndiz et al. 2018). Finalmente, no hubo diferencias significativas en la frecuencia cardíaca de las tortugas entre los 4 grupos $(F=0.53$, g.l. $=3, P=0.66)$ (Fig. 2b).

\section{Discusión}

En tortugas marinas, la temperatura cloacal puede ser representativa de la temperatura ambiental (Southwood et al. 2003, Foley et al. 2007). Utilizando los intervalos de referencia de organismos sanos, los rehabilitadores de animales silvestres pueden responder rápidamente a eventos de tortugas aturdidas por frío, lo cual aumenta sus posibilidades de recuperación (Wyneken et al. 2006). No obstante, la técnica para el registro de la temperatura cloacal es moderadamente invasiva y puede resultar dolorosa para los organismos (Manire et al. 2017). Los valores de la temperatura del área inguinal izquierda registrados en la presente investigación coincidieron con la temperatura corporal reportada previamente para tortugas sanas (Southwood et al. 2003, Hunt et al. 2019), y el presente estudio confirmó que el uso del termómetro infrarrojo digital en el área inguinal 


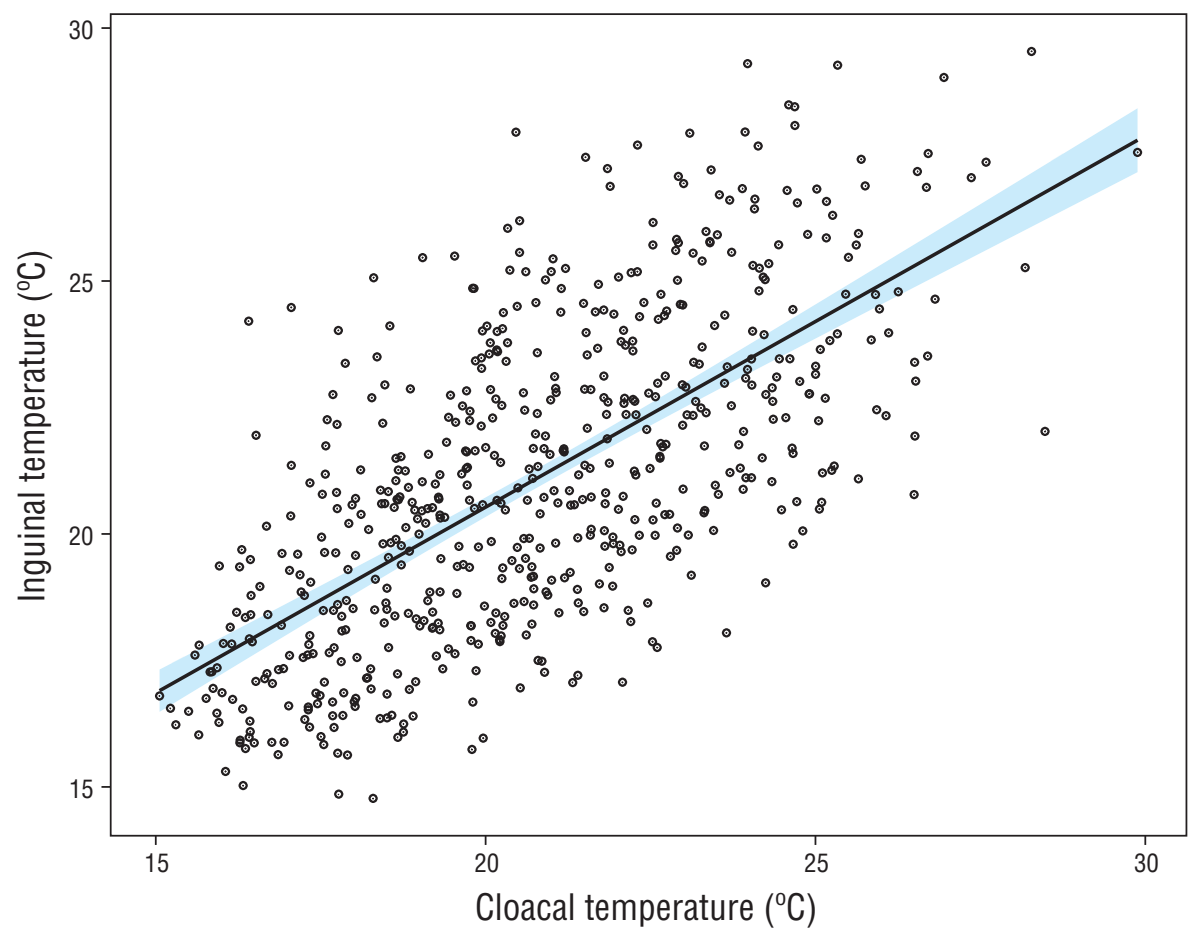

Figure 1. Linear regression between cloacal and inguinal area temperatures for black turtles (Chelonia mydas) in the present study.

Figura 1. Regresión lineal entre las temperaturas de la zona cloacal y la zona inguinal izquierda de las tortugas negras (Chelonia mydas) del presente estudio.
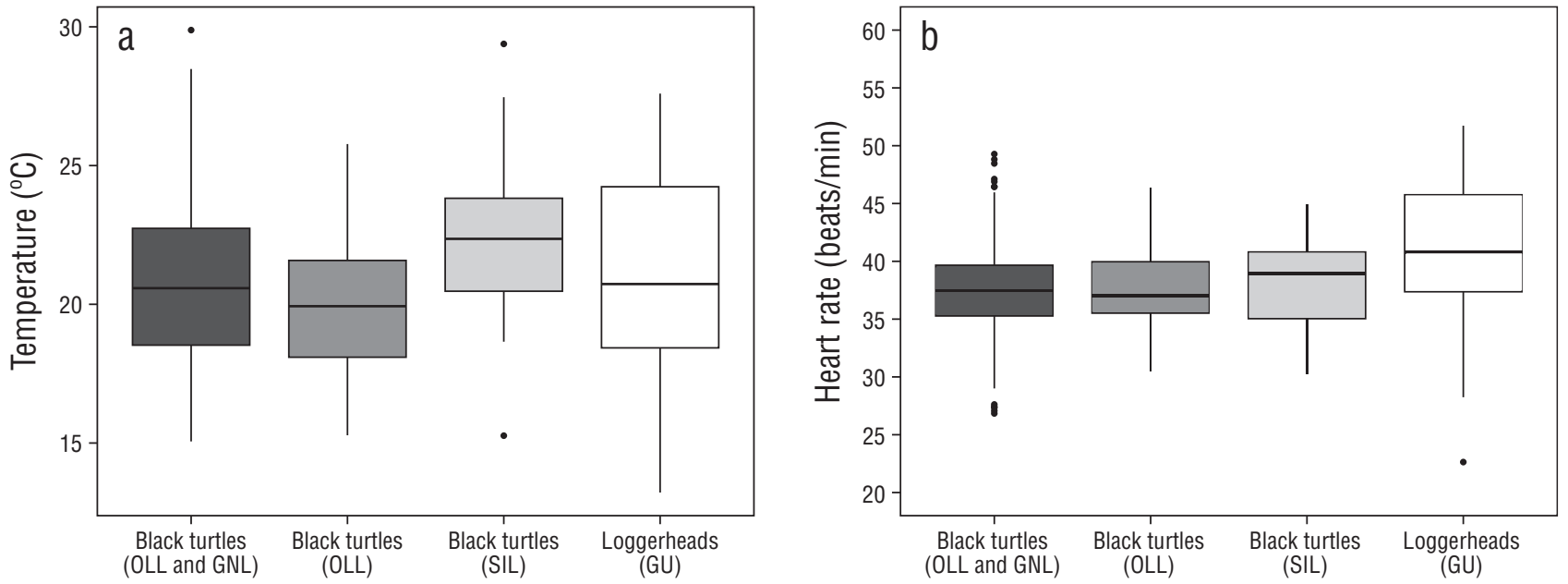

Figure 2. Cloacal temperature (a) and heart rate (b) for black turtles (Chelonia mydas) in Ojo de Liebre Lagoon (OLL) and Guerrero Negro Lagoon (GNL) (present study), black turtles in OLL and San Ignacio Lagoon (SIL) (Reséndiz et al. 2018), and loggerhead turtles (Caretta caretta) in the Gulf of Ulloa (GU) (Reséndiz et al. 2019).

Figura 2. Temperaturas cloacal (a) y frecuencia cardíaca (b) de tortugas negras (Chelonia mydas) de laguna Ojo de Liebre (OLL) y laguna Guerrero Negro (GNL) (presente estudio), tortugas negras de OLL y laguna San Ignacio (SIL) (Reséndiz et al. 2018) y tortugas amarillas (Caretta caretta) del golfo de Ulloa (GU) (Reséndiz et al. 2019). 
1985). Both lagoons flow into the Sebastián Vizcaíno Bay, a biological active center that is located within the California Current region, where northwesterly winds create one of the main coastal upwelling regions (Lluch-Belda 2000). SIL is located further south and occupies an area of $175 \mathrm{~km}^{2}$ (Contreras 1985). This lagoon flows into the GU, which is also considered a biological active center with coastal upwelling (Lluch-Belda 2000). The surface, geographic location, and oceanographic conditions of the different sites can explain the differences in water temperature and hence the organisms.

Cardiac auscultation in sea turtles allows us to identify basic physiological alterations or certain pathological processes (Butler et al. 1984, Hunt et al. 2019), which are often initially described as tachycardia and bradycardia. Under controlled conditions (sea turtle hospitals and rehabilitation centers) heart rate is recorded with a Doppler probe or ultrasound, and the use of a stethoscope is unconventional (Norton 2005). However, our results showed that the use of the stethoscope is a novel and effective technique for assessing heart rate in free-ranging sea turtle populations. The heart rates for black turtles in the present study were similar to those reported by Southwood et al. (1999), Norton (2005), and Reséndiz et al. $(2018,2019)$ for healthy sea turtles at a temperature of $24^{\circ} \mathrm{C}$, which ranged from 30 to 60 beats per minute. There were no significant differences between black turtle heart rates in this study and previously reported data for black turtles in OLL and SIL, and loggerheads in GU, indicating that these data are an accurate representation for the species. This basic diagnostic orientation tool allows us to rule out health abnormalities such as cold-stunning, signs of respiratory problems, lung lesions, and other pathological changes related to the respiratory system (Reséndiz et al. 2019).

In summary, body temperature and heart rate data for OLL and GNL black turtles were generated and compared with previous reports. This information provides further insight into the variation of vital signs between different species of sea turtles in nearby areas. The use of the digital infrared thermometer in the left inguinal area proved to be an easier, effective, and less invasive measurement technique than taking the cloacal temperature. The minimally invasive diagnostic approach using vital signs described here allows us to evaluate and infer core physiological functions, including general cardiopulmonary status, and rule out health threats such as cold-stunning, resulting in a useful preliminary systemic assessment of free-ranging sea turtles.

\section{ACKNowledgments}

This research was conducted with all the required research permits authorized by the Secretaría de Medio Ambiente y Recursos Naturales (Mexico). Thanks to Everardo Mariano, Oscar Salazar, Noé López, Gabriel Zaragoza, and José Buelna with REBIVI-CONANP for their support and izquierda representa una técnica de medición eficaz, más fácil y menos invasiva. Aunque ambas áreas presentaron una relación estadísticamente positiva, el valor de $R^{2}$ es mediobajo y debe interpretarse con cuidado. Recomendamos utilizar este tipo de termómetro (debidamente calibrado) y registrar la temperatura corporal cuando la tortuga acaba de ser capturada para registrar los valores más representativos y evitar sesgos por estrés o factores externos como la temperatura ambiental. La comparación de la temperatura entre grupos mostró que las tortugas de LSI presentaron temperaturas cloacales significativamente más altas que las de LOL y LGN, lo que se puede atribuir a las condiciones de las masas de agua en las que habitan. LOL y LGN están interconectadas y juntas ocupan un área de $381 \mathrm{~km}^{2}$ (Contreras 1985). Ambas lagunas desembocan en la bahía Sebastián Vizcaíno, un centro de actividad biológica que se ubica dentro de la región de la corriente de California, donde los vientos del noroeste producen una de las principales regiones de afloramiento costero (Lluch-Belda 2000). LSI se encuentra más al sur y ocupa un área de $175 \mathrm{~km}^{2}$ (Contreras 1985). Esta laguna desemboca en el GU, que también se considera un centro de actividad biológica con afloramiento costero (Lluch-Belda 2000). La superficie, la ubicación geográfica y las condiciones oceanográficas de los diferentes sitios pueden explicar las diferencias en la temperatura del agua y, por tanto, en los organismos.

La auscultación cardíaca en tortugas marinas permite identificar alteraciones fisiológicas básicas o ciertos procesos patológicos (Butler et al. 1984, Hunt et al. 2019), que a menudo se describen inicialmente como taquicardia y bradicardia. En condiciones controladas (hospitales de tortugas marinas y centros de rehabilitación), la frecuencia cardíaca se registra con una sonda Doppler o con un ultrasonido, y el uso de un estetoscopio no es convencional (Norton 2005). Sin embargo, nuestros resultados mostraron que el uso del estetoscopio es una técnica novedosa y eficaz para evaluar la frecuencia cardíaca en poblaciones de tortugas marinas en vida libre. Las frecuencias cardíacas de las tortugas negras del presente estudio fueron similares a las reportadas por Southwood et al. (1999), Norton (2005) y Reséndiz et al. $(2018,2019)$ para tortugas marinas saludables a una temperatura de $24{ }^{\circ} \mathrm{C}$ (de 30 a 60 latidos por minuto). No hubo diferencias significativas entre la frecuencia cardíaca de las tortugas negras de este estudio y los datos reportados previamente para las tortugas negras en LOL y LSI, y las tortugas amarillas de GU, lo que sugiere que estos datos son una representación precisa de estas especies. Esta herramienta básica de orientación diagnóstica permite descartar anomalías de salud como el frío paralizante, indicios de problemas respiratorios, lesiones pulmonares y otros cambios patológicos relacionados con el sistema cardiorrespiratorio (Reséndiz et al. 2019).

En conclusión, se generaron los valores de temperatura corporal y frecuencia cardíaca de las tortugas negras de LOL y LGN y se compararon con reportes previos. Esta 
guidance during the research development. Thanks are also due to Aarón Sanchez, Fabián Castillo, Joaquín Rivera, and Antonio Zaragoza with Empresa Exportadora de Sal in Guerrero Negro for their help with the field work and logistics.

\section{REFERENCES}

Aguirre AA, Lutz PL. 2004. Marine turtles as sentinels of ecosystem health: is fibropapillomatosis an indicator? EcoHealth. 1:275-283. https://doi.org/10.1007/s10393-004-0097-3

Arthur K, Limpus C, Balazs G, Capper A, Udy J, Shaw G, KeuperBennett U, Bennett P. 2008. The exposure of green turtles (Chelonia mydas) to tumour promoting compounds produced by the cyanobacterium Lyngbya majuscula and their potential role in the aetiology of fibropapillomatosis. Harmful Algae. $7(1): 114-125$. https://doi.org/10.1016/j.hal.2007.06.001

Balazs GH. 1999. Factors to consider in the tagging of sea turtles. In: Eckert K, Bjorndal K, Abreu-Grobois A, Donnelly M (eds.), Research and Management Techniques for the Conservation of Sea Turtles. IUCN/SSC Marine Turtle Specialist Group, Publication No. 4. Washington DC: International Union for Conservation of Nature.

Bolten AB. 1999. Techniques for measuring sea turtles. In: Eckert K, Bjorndal K, Abreu-Grobois A, Donnelly M (eds.), Research and Management Techniques for the Conservation of Sea Turtles. IUCN/SSC Marine Turtle Specialist Group, Publication No. 4. Washington DC: International Union for Conservation of Nature.

Butler PJ, Milsom WK, Woakes AJ. 1984. Respiratory, cardiovascular and metabolic adjustments during steady state swimming in the green turtle, Chelonia mydas. J Comp Physiol. 154:167-174. https://doi.org/10.1007/bf00684141

Contreras F. 1985. Lagunas costeras mexicanas, Centro de Ecodesarrollo. México: Secretaría de Pesca.

[ESSA] Empresa exportadora de sal. 2018. Informe anual de los monitoreos de tortugas marinas en el complejo lagunar Ojo de Liebre BCS, México. Guerrero Negro (Baja California Sur, Mexico): ESSA, Gerencia de Gestión Integral y Planeación. $145 \mathrm{p}$.

Foley AM, Singel KE, Dutton PH, Summers TM, Redlow AE, Lessman J. 2007. Characteristics of a green turtle (Chelonia mydas) assemblage in northwestern Florida determined during a hypothermic stunning event. Gulf Mex Sci. 25(2):131-143. https://doi.org/10.18785/goms.2502.04

Hunt KE, Innis C, Merigo C, Burgess EA, Norton T, Davis D, Kennedy AE, Buck CL. 2019. Ameliorating transport-related stress in endangered Kemp's ridley sea turtles (Lepidochelys kempii) with a recovery period in saltwater pools. Conserv Physiol. 7(1):coy065. https://doi.org/10.1093/conphys/coy065

Innis CJ, Tlusty M, Merigo C, Weber ES. 2007. Metabolic and respiratory status of cold-stunned Kemp's ridley sea turtles (Lepidochelys kempii). J Comp Physiol B. 177:623-630. https://doi.org/10.1007/s00360-007-0160-9

Lluch-Belda D. 2000. Centros de Actividad Biológica en la costa de Baja California. In: Lluch-Belda D, Elorduy-Garay JF, LluchCota SE, Ponce-Díaz G (eds.), BAC: Centros de Actividad Biológica del Pacífico Mexicano. Mexico: Centro de Investigaciones Biológicas del Noroeste. p. 49-64. información muestra cómo varían los signos vitales entre las diferentes especies de tortugas marinas en áreas cercanas. Se confirmó que el uso del termómetro digital infrarrojo en el área inguinal izquierda representa un método de medición eficaz, más fácil y menos invasivo que la técnica tradicional de medición de la temperatura cloacal. Este enfoque diagnóstico mínimamente invasivo por medio de signos vitales permite evaluar e inferir funciones fisiológicas centrales, incluso el estado cardiopulmonar general, y descartar amenazas de salud como el frío paralizante, lo cual resulta útil como evaluación sistémica inicial en tortugas marinas en vida libre.

\section{Agradecimientos}

Esta investigación se realizó con todos los permisos de investigación necesarios autorizados por la Secretaría de Medio Ambiente y Recursos Naturales (México). Los autores agradecen a Everardo Mariano, Oscar Salazar, Noé López, Gabriel Zaragoza y José Buelna de la REBIVI-CONANP, por su apoyo y guía durante el desarrollo de esta investigación. Gracias a Aarón Sánchez, Fabián Castillo, Joaquín Rivera y Antonio Zaragoza del área de Conservación ambiental, Gerencia de Gestión Integral y Planeación de la Empresa Exportadora de Sal de Guerreo Negro, por su asistencia durante el trabajo de campo y logística.

Manire CA, Norton TM, Stacy BA, Innis CJ, Harms CA. 2017. Sea Turtle Health \& Rehabilitation. Plantation (FL): J Ross Publishing. $1045 \mathrm{p}$.

Márquez R. 1990. FAO Species Catalogue. Vol. 11: Sea turtles of the world. An annotated and illustrated catalog of sea turtle species known to date. Rome (Italy): Food and Agriculture Organization of the United Nations (FAO). $81 \mathrm{p}$.

Norton TM. 2005. Chelonian emergency and critical care. Topics in medicine and surgery. Semin Avian Exot Pet Med. 14(2):106-130.

https://doi.org/10.1053/j.saep.2005.04.005

Reséndiz E, Fernández-Sanz H, Barrientos-Torres DS, Lara-Uc MM. 2019. Clinical pathology and health reference values for loggerhead sea turtles (Caretta caretta) and olive ridley turtles (Lepidochelys olivacea) in the Gulf of Ulloa, Baja California Sur, Mexico. Comp Clin Path. 28(6):1637-1650.

https://doi.org/10.1007/s00580-019-02985-0

Reséndiz E, Fernández-Sanz H, Lara-Uc MM. 2018. Baseline health indicators of Eastern Pacific green turtles (Chelonia mydas) from Baja California Sur, Mexico. Comp Clin Path. 27(5):1309-1320. https://doi.org/10.1007/s00580-018-2740-3

Schwartz FJ. 1978. Behavioral and tolerance responses to cold water temperatures by three species of sea turtles (Reptilia, Cheloniidae) in North Carolina. Fla Mar Res Publ. 33:16-18.

Southwood AL, Andrews RD, Lutcavage ME, Paladino FV, West NH, George RH, Jones DR. 1999. Heart rates and diving behavior of leatherback sea turtles in the eastern Pacific Ocean. J Exp Biol. 202(Pt 9)(9):1115-1125. 
Southwood AL, Darveau CA, Jones DR. 2003. Metabolic and cardiovascular adjustments of juvenile green turtles to seasonal changes in temperature and photoperiod. J Exp Biol. 206(24):4521-4531.

https://doi.org/10.1242/jeb.00689

Van Houtan KS, Smith CM, Dailer ML, Kawachi M. 2014. Eutrophication and the dietary promotion of sea turtle tumors.
PeerJ. 2:e602.

https://doi.org/10.7717/peerj.602

Wyneken J, Mader DR, Weber III ES, Merigo C. 2006. Medical care of seaturtles. In: Mader DM (ed.), Reptile Medicine and Surgery. 2nd ed. St. Louis (MO): Saunders Elsevier. p. $972-1007$.

https://doi.org/10.1016/B0-72-169327-X/50080-8

Received 24 July 2020,

accepted 2 October 2020. 